\title{
Allocation Pattern in the Financing of Colleges of Legal and Islamic Studies in Nigeria
}

\author{
A. S. Omosidi ${ }^{1}$ \\ ${ }^{1}$ Department of Educational Management, University of Ilorin [*E-mail: \\ abdulrahmanomosidi@yahoo.com]
}

\begin{abstract}
This study investigated the allocation pattern in the financing of colleges of Legal and Islamic Studies in Nigeria with special regard to the adequacy of the funding. The sample consisted of eight out of the twelve colleges of Legal and Islamic Studies in the country. A research instrument titled "Financial Allocation Questionnaire" was used to collect data. The findings showed that there is general under-funding of these colleges within the period considered. Even in the face of inflation and staff and students expansion, there was little or no increase in the colleges' annual capital grants and monthly subventions. Grounded on these findings, recommendations towards the better funding of the colleges are made.
\end{abstract}

Keywords: Financial management; Funding; Islamic Studies.

\section{$1 \quad$ Introduction}

The fourth National Development Plan (1981-1985) stated that: 'education has continued to play a crucial role in our economic development and social transformation process. Successive Governments, in recognition of this role, have accorded it a high priority in the structure of resource allocation" (FRN, 2004).

To implement this policy, the federal and state governments are annually making some remarkable increase in the proportion of overall budget allocated to education with a view to increasing the possibilities of mobilizing enough resources for educational institutions. In view of this, laudable policies are drawn up in establishing educational institutions, such as Colleges of Legal and Islamic Studies in various northern states of the Nigeria for the training of required middle level manpower in Islamic Legal Education in particular and 
for social, economic and political development in general. Some of these institutions are College of Arabic and Islamic Legal Studies, Ilorin established in 1992, Aminu Kano College of Legal and Islamic Studies, Kano, established in 1974, A.D. Rufai College of Legal and Islamic studies, Missau, Bauchi state established, 1975, Justice Fati Abubakar College of Arts and Legal and Islamic Studies, Minna, Niger state established in 1990 among others.

The burden of financing the colleges rests on the proprietors, solely the state governments. But the Government of the concerned states have limited resources to cater for the institutions' needs. Generally, the resources available to the government in Nigeria are dwindling (Abdulkareem, 1999). As a result of this situation, the financial allocations to the college have continued to be inadequate. For Instance, In Kwara State College of Arabic and Islamic Legal Studies, Ilorin, the percentage of state financial allocations were $43.45 \%$ in $2010,62.85 \%$ in $2011,63.74 \%$ in $2012,74.01 \%$ in 2013 and $63.59 \%$ in 2014. These figures revealed an annual increase in the percentage of allocation from the state, except for year 2013. Despite the increase, the state government did not meet up the required estimates of the institution between 2010 and 2014 . This situation was the same in most of the colleges. Hence, the institutions are compelled to source for extra funds for their needs.

In sourcing for funds, the colleges resorted to enrolling many students and even degree programmes which are beyond their primary assignments of producing middle level manpower for the country in Arabic and Islamic Legal Studies. The choice of these alternatives was intended to supplement the inadequate monthly subventions from the governments. The increase in enrolments and the running of degree programmes meant that resources (money, men and materials) will have to be employed for use. It is based on this background that this research work was carried out to bring to the limelight the allocation pattern of financing in the colleges.

\subsection{Objectives of the Study}

The specific objectives of the study were:

1. To determine the estimates and actual amount of recurrent expenditure in Colleges of Legal and Islamic Studies in Nigeria between 2010 and 2014.

2. To determine the estimates and actual amount of capital expenditure in Colleges of Legal and Islamic Studies in Nigeria between 2010 and 2014.

3. To determine the cost per student in Colleges of Legal and Islamic Studies in Nigeria between 2010 and 2014

4. To determine the utilization pattern of fund allocated to Colleges of Legal and Islamic Studies in Nigeria between 2010 and 2014

5. To determine how much was the internally generated revenue by Colleges of Legal and Islamic Studies in Nigeria between 2010 and 2014. 


\subsection{Related Literature}

Introduction of western education in Nigeria dates back to 1842 when the Wesleyan Methodist Society opened a Christian Missionary Station in Badagry near Lagos. The sources of fund then were contributions from the native believers, and donations from organizations abroad. Nwankwo (1981) revealed that the missionaries brought education and dominated its funding and control up till 1970 when the state Governments took over the funding of education. Onabamiro (1982) observed that government funding for formal education was first made in 1887 when the government in Lagos gave a grant of 200 pounds to each of the three Christian Societies.

However, out of the hundred and fifty schools in the southern Nigeria in 1911 that had a link with government financial benefit, ninety one were funded by the missionaries while the remaining fifty-nine enjoyed government subvention fully. During this period, there were 3,984 pupils in the government partially funded schools; according to the report of the director of education of $5^{\text {th }}$ July 1913. With this initial government contribution to the missionary education, the colonial government felt that "he who played the piper must dictate the tune'. As a result, by 1882, the first educational ordinance was passed regularizing the school system and laying down conditions for grant-inaid.

The 1882 ordinance was followed by the 1887 education ordinance and later the 1916 education ordinance all with gradual improvement in the financial involvement of the government in education vis-à-vis the missionary efforts. The education ordinance of 1926 was the result of the efforts of the Phelps Stokes' report and 1925 memorandum. The ordinance aimed at checking the proliferation of poor quality schools by improving government financial aids to education. Although, the period between 1926 and 1929 was one of the relative financial prosperity. Omosidi (2007) citing Adaralegbe opined that " the 1925 education code regulations in terms of grant-in-aid were never fully effective because of the great economic depression which began in Nigeria in 1930".

There was a rapid increase in education budget from 1955. This increase was necessitated by the introduction of the Universal Primary Education (UPE) project by some regional governments and the proliferation and expansion of facilities in public schools. According to Ojo (1983), allocations to education became the simplest largest item in the budgets of the former regional government between 1955 and 1966. Furthermore, Ojo (1983) summarized the development in the funding of education from the mid-fifties and the midsixties as follows;

From the mid-fifties to the mid-sixties, the Nigeria government aggregate expenditure on education increase at a faster rate than Gross Domestic Product (GDP) and over all government expenditure. The annual compound growth 
rates of expenditure on education during the 1960-66, for example, averaged about 15 percent. And from 1955 to 1963, recurrent expenditure on education increase at an annual growth rate of 15.5 percent while the rate of increase in overall expenditure was 10.5 percent (pp.22-23).

There was a gradual development of education finance in Nigeria until 1970 when the government took over responsibility of all schools from the missionaries both in funding and control. As a result of this, the National Policy on Education (NPE) was published in 1981, revised in 1985 and also revised 2004. The policy spelt out in clear terms the stand of the Nigeria government on education financing. NPE (2004) stated that:

Education in Nigeria is no more a private enterprise, but the huge government venture that has witnessed a progressive evolution of government's complete and dynamic intervention and active participation. The Federal Government of Nigeria has adopted education as an instrument par excellence for effecting National Development. It is only natural then that government should clarify the philosophy and objectives that underline its current massive investment in education and spell out in clear unequivocal terms the policies that guide government educational efforts (p.5)

\subsection{Research Questions}

The following research questions were raised to guide the investigator in this collection and analysis of data.

1. What are the estimates and actual amount of recurrent expenditure in Colleges of Legal and Islamic Studies in Nigeria between 2010 and 2014?

2. What are the estimates and actual amount of capital expenditure in Colleges of Legal and Islamic Studies in Nigeria between 2010 and 2014?

3. What is the cost per student in Colleges of Legal and Islamic Studies in Nigeria in the period between 2010 and 2014?

4. What is the utilization pattern of fund allocation to Colleges of Legal and Islamic Studies in Nigeria in the period between 2010 and 2014?

5. How much was the internally generated revenue by Colleges of Legal and Islamic Studies in Nigeria in the period between 2010 and 2014?

\section{$2 \quad$ Methodology}

This is a longitudinal study spanning a period of five years from 2009/2010 to 2013/2014. The five years period was selected because it was felt that the time span would give a clearer, wider and more reliable overview of the situation. The population for the study consisted of all the twelve Colleges of Legal and Islamic Studies in Northern Nigeria. These comprises of three zones (that is, 
North Central, North East, and North West). However, eight colleges were purposively selected for the study. These were colleges of legal and Islamic studies, Ilorin, Kano, Minna, Bauchi, Jigawa, Yola, Kebbi and Maiduguri. They have also been in existence for more than ten years, therefore suitable for a longitudinal study such as this. Hence their selection as the population sample.

The collection of data was done through the use of a questionnaire titled Financial Allocation Questionnaire (FAQ), which is consisted of information on estimates generated revenue and donations from international agencies. The questionnaire was validated through face and content validities. A test-retest reliability co-efficient of 0.76 was obtained. The data collected were analysed descriptively.

\section{$3 \quad$ Findings and Discussion}

\subsection{Estimates and Actual Amount of Recurrent Expenditure}

The findings on the estimates and actual amount of recurrent expenditure in the Colleges of Legal and Islamic Studies (2010 to 2014) are summarised in Table 1. 
Table 1: Estimated and Actual Recurrent Expenditure (2010 to 2014)

\begin{tabular}{|c|c|c|c|c|c|c|c|c|c|c|c|c|c|c|c|c|c|c|}
\hline & & 2010 & & & 2011 & & & 2012 & & & 2013 & & & 2014 & & & Total & \\
\hline & $a$ & $b$ & c & $a$ & $b$ & c & a & $b$ & c & a & $b$ & c & a & $b$ & c & $a$ & $b$ & c \\
\hline $\begin{array}{l}\text { CAILS, } \\
\text { Ilorin }\end{array}$ & 20 & 17.9 & 89.5 & 60.91 & 52.39 & 86.01 & 72.9 & 60.68 & 83.24 & 77.6 & 63.57 & 81.92 & 80.97 & 63.57 & 78.51 & 312.38 & 258.11 & 82.63 \\
\hline SILS, Kano & 31.65 & 29.44 & 93.02 & 80.6 & 71.51 & 88.72 & 82.75 & 78.28 & 94.6 & 83.3 & 78.78 & 94.57 & 84.7 & 78.78 & 93.01 & 363 & 336.79 & 92.78 \\
\hline $\begin{array}{l}\text { CAILS, } \\
\text { Missau }\end{array}$ & 19.88 & 16.69 & 83.95 & 59.27 & 46.79 & 78.94 & 62.74 & 48.97 & 78.05 & 67.47 & 59.69 & 88.47 & 75.69 & 59.69 & 78.86 & 285.05 & 231.83 & 81.33 \\
\hline $\begin{array}{l}\text { CILS, } \\
\text { Minna }\end{array}$ & 22.69 & 21.69 & 95.59 & 66.4 & 62.69 & 94.41 & 67.65 & 64.95 & 96.01 & 68.78 & 65.96 & 95.9 & 70.96 & 65.96 & 92.95 & 296.48 & 281.25 & 94.86 \\
\hline $\begin{array}{l}\text { CILS, } \\
\text { Ringim }\end{array}$ & 10.96 & 8.93 & 81.48 & 35.69 & 33.7 & 94.42 & 38.12 & 37.68 & 98.85 & 40 & 39.18 & 97.95 & 42.78 & 39.18 & 91.58 & 167.55 & 158.67 & 94.7 \\
\hline CILS, Yola & 11.7 & 11.69 & 99.91 & 34.35 & 32.23 & 93.83 & 41.69 & 39.91 & 95.73 & 47.97 & 48.47 & 101.04 & 52.94 & 48.47 & 91.56 & 188.65 & 180.77 & 95.82 \\
\hline $\begin{array}{l}\text { CAILS, } \\
\text { Yauri }\end{array}$ & 18.44 & 17.93 & 97.23 & 54.92 & 52.89 & 96.3 & 55.13 & 53.91 & 97.79 & 56.22 & 54.68 & 97.26 & 58.26 & 54.68 & 93.86 & 242.97 & 234.09 & 96.35 \\
\hline $\begin{array}{l}\text { CILS, } \\
\text { Maiduguri }\end{array}$ & 28.21 & 26.46 & 93.8 & 98.37 & 95.67 & 97.26 & 101.37 & 96.26 & 94.96 & 104.17 & 96.2 & 92.35 & 107.32 & 96.2 & 89.64 & 439.44 & 410.79 & 93.48 \\
\hline Total & 163.53 & 150.73 & 92.17 & 490.51 & 447.87 & 91.31 & 522.35 & 480.64 & 92.01 & 545.51 & 506.53 & 92.85 & 573.62 & 506.53 & 88.3 & 2295.52 & 2092.3 & 91.15 \\
\hline
\end{tabular}


Table 1 shows the financial request of each of the institutions and government allocation on recurrent expenditure in the last five years (2010-2014). Also, from the table, the total estimated recurrent expenditure in the colleges under this study between 2010 and 2014 was 2.3 billion compared to the governments approved allocation on recurrent expenditure of N2.1 billion in the same period.

This shows that each state government under this study was able to meet $90.58 \%$ each of the institution's request. It was discovered that all the institutions under this study were under funded by $9.42 \%$ when all the sources are considered. Despite that the various state governments in this study met $90.58 \%$ of the recurrent expenditure requested, there was no institution however that had all her financial request met. This position showed that recurrent expenditure was the major priority of most of the state governments under this study. This finding confirmed the view of Lawal (1989) that Ogun State government contributed only $74 \%$ of the average revenue required by secondary schools in Ogun state between 1981 and 1986.

\subsection{Estimates and Actual Amount of Capital Expenditure}

The findings on the estimates and actual amount of capital expenditure in the Colleges of Legal and Islamic Studies (2010 to 2014) are summarised in Table 2. 
Table 2: Estimated and Actual Capital Expenditure (2010 to 2014)

\begin{tabular}{|c|c|c|c|c|c|c|c|c|c|c|c|c|c|c|c|c|c|c|}
\hline & \multicolumn{3}{|c|}{2010} & \multicolumn{3}{|c|}{2011} & \multicolumn{3}{|c|}{2012} & \multicolumn{3}{|c|}{2013} & \multicolumn{3}{|c|}{2014} & \multicolumn{3}{|c|}{ Total } \\
\hline & a & b & C & a & b & c & a & b & C & a & $\mathrm{b}$ & c & a & b & c & $\mathrm{a}$ & b & c \\
\hline CAILS, Ilorin & 22.09 & 35 & 1.58 & 22.59 & .09 & .4 & 28.58 & 4 & 13.99 & 26.23 & 15 & 57.19 & 29.69 & 6.8 & 22.9 & 129.17 & 26.24 & 20.31 \\
\hline SILS, Kano & 15.89 & - & - & 17.59 & - & - & 26.12 & 19.35 & 74.08 & 18.2 & 5.88 & 32.31 & 35.48 & 21.69 & 61.13 & 113.28 & 46.84 & 41.35 \\
\hline CAILS, Missau & 15.69 & - & - & 17.13 & - & - & 19.01 & - & - & 1.96 & - & - & 19.99 & 6.76 & 33.82 & 91.42 & 6.76 & 7.39 \\
\hline CILS, Minna & 28.64 & 25 & 87.29 & 20.61 & 17 & 82.48 & 25.67 & - & - & 30.15 & - & - & 75.26 & 55 & 73.08 & 180.32 & 97 & 53.79 \\
\hline CILS, Ringim & 19.98 & 1.50 & 7.51 & 16.75 & 2 & 11.94 & 17.4 & - & - & 20.71 & - & - & 22.82 & 15.78 & 69.15 & 97.65 & 17.8 & 18.23 \\
\hline CILS, Yola & 11.7 & 11.69 & 99.91 & 34.35 & 32.23 & 93.83 & 41.69 & 39.91 & 95.73 & 47.97 & 48.47 & 101.04 & 52.94 & 48.47 & 91.56 & 188.65 & 180.77 & 95.82 \\
\hline CAILS, Yauri & 18.69 & 2.75 & 14.71 & 20.12 & - & - & 22.58 & - & - & 23.3 & 11.75 & 50.43 & 25.66 & - & - & 110.35 & 14.5 & 13.14 \\
\hline CILS, Maiduguri & 17.95 & 2.7 & 15.04 & 19.5 & 1.5 & 7.69 & 21.54 & 3.7 & 17.18 & 22.44 & 2 & 8.91 & 24.5 & 7 & 28.57 & 105.93 & 16.9 & 15.95 \\
\hline Total & 154.7 & 36.3 & 23.46 & 147.6 & 29.59 & 20.03 & 178.5 & 30.55 & 17.11 & 180.1 & 34.63 & 19.22 & 257 & 113 & 43.97 & 917.8 & 242.5 & 26.43 \\
\hline
\end{tabular}

Key: a. College Estimate; b. Amount allocated; c. Percentage amount allocated

Source: Bursary Department of each institution 
Table 2 revealed the financial request of the institutions and government subventions on capital expenditure in the last five years (2010-2014). On the average, the total amount estimated on capital expenditure in the colleges between 2010 and 2014 was 917.8 million compared to the government subventions of 242.3 million on capital expenditure between 2010 and 2014. This amount shows that each of the state government in this study was able to meet only $26.43 \%$ of the requests of the institutions. This indicated that much attention was not given to capital expenditure compared to recurrent expenditure. It shows that capital projects in most of the colleges were either abandoned or new ones were not executed.

The implication of this was that the institutions were expected to generate fund internally to complement the government efforts. Also complementing each state government efforts was the Federal Government Allocation through the Education Trust Fund (ETF). However, the requests on capital expenditure in each of the colleges under this study between 2010 and 2014 were not met. All the colleges were under funded by $74.57 \%$ meaning that only $26.43 \%$ of the financial needs were met on capital expenditure through Federal Government allocation (ETF), and internally generated fund. This position was affirmed by Ajayi (1998) who studied the effective financing of private secondary schools in Ekiti state. This study revealed that only $1.1 \%$ of the fund allocated was spent on capital project.

\subsection{Unit Costs}

The findings on the costs per student in the Colleges of Legal and Islamic Studies in Nigeria in the period between 2010 and 2014 are summarised in Table 3.

Table 3: Unit Cost per student (2010 and 2014)

\begin{tabular}{lcccccc}
\hline & $\begin{array}{c}\text { Expenditur } \\
\text { es }\end{array}$ & $\begin{array}{c}\text { Government } \\
\text { recurrent } \\
\text { expenditure }\end{array}$ & $\begin{array}{c}\text { Government } \\
\text { capital } \\
\text { expenditure }\end{array}$ & $\begin{array}{c}\text { Students } \\
\text { enrolment }\end{array}$ & $\begin{array}{c}\text { Unit } \\
\text { cost per } \\
\text { college }\end{array}$ & $\begin{array}{c}\text { Unit } \\
\text { cost per } \\
\text { student }\end{array}$ \\
\hline CAILS, Ilorin & $282,664,823$ & $256,424,823$ & $26,240,000$ & 5,166 & $32,619$. & 6,524 \\
SILS, Kano & $383,151,278$ & $336,309,778$ & $46,481,500$ & 10,236 & 22,093 & 4,418 \\
CAILS, Missau & $232,582,104$ & $225,821,104$ & $6,761,000$ & 3,951 & 27,229 & 5,445 \\
CILS, Minna & $377,833,720$ & $280,833,720$ & $97,000,000$ & 5,746 & 67,670 & 13,534 \\
CILS, Ringim & $176,267,691$ & $158,470,131$ & $17,797,560$ & 7,265 & 25,226 & 5,045 \\
CILS, Yola & $187,491,649$ & $170,997,649$ & $1,650,000$ & 4,666 & 41,582 & 8,316 \\
CAILS, Yauri & $237,891,532$ & $233,391,532$ & $14,500,000$ & 4,019 & 36,549 & 7,309 \\
CILS, Maiduguri & $458,810,731$ & $411,910,731$ & $16,900,000$ & 10,492 & 19,139 & 3,827 \\
Total & $2,231,699,528$ & $2,074,159,468$ & $242,540,060$ & 51,141 & 272,109 & 54,422 \\
\hline
\end{tabular}

Source: Bursary Department of each institution 
Table 3 shows the total expenditure, student enrolment, unit cost per college and cost per student in Colleges of Legal and Islamic Studies in Nigeria in five years $(2009 / 2010$ to $2013 / 2014)$. The total expenditure from 2009/2010 to $2013 / 2014$ was divided by the total number of students in the same period to obtain the unit cost per college. This figure was later divided by the number of years to obtain unit cost per student in each institution.

On the average N 6,802.76 was spent on every student in Colleges of Legal and Islamic studies in Nigeria in the period between 2010 and 2014. This implied that the unit cost in most of the college was high. Education is a social service in any nation; therefore every citizen in a country must have free access to education. Longe (1981) discovered that the average unit cost per student per year varies between N159.36 and N236.28 in rural schools and between N120.00 and N378.71 in urban areas.

\subsection{Pattern of Utilising Funds Allocated}

Table 4 shows the pattern of utilising the funds allocated to the colleges during the period studied. 
Table 4: Utilization Pattern of Funds Allocated to the Colleges (2010 to 2014)

\begin{tabular}{|c|c|c|c|c|c|c|c|c|c|c|c|c|c|c|c|c|}
\hline \multirow[t]{2}{*}{ Institution } & \multicolumn{2}{|c|}{$\begin{array}{l}\text { Salaries \& } \\
\text { allowances }\end{array}$} & \multicolumn{2}{|c|}{ Staff training } & \multicolumn{2}{|c|}{$\begin{array}{c}\text { Staff seminars/ } \\
\text { conferences }\end{array}$} & \multicolumn{2}{|c|}{ Publications } & \multicolumn{2}{|c|}{$\begin{array}{c}\text { Supervision/ } \\
\text { attachment } \\
\text { allowances }\end{array}$} & \multicolumn{2}{|c|}{ Utilities } & \multicolumn{2}{|c|}{$\begin{array}{c}\text { Capital } \\
\text { expenditure }\end{array}$} & \multicolumn{2}{|c|}{ Total } \\
\hline & Amount & $\%$ & Amount & $\%$ & Amount & $\%$ & Amount & $\%$ & Amount & $\%$ & Amount & $\%$ & Amount & $\%$ & Amount & $\%$ \\
\hline $\begin{array}{l}\text { CAILS, } \\
\text { llorin }\end{array}$ & 214.62 & 75.93 & 12.54 & 4.44 & 9.4 & 3.33 & 4.02 & 1.42 & 8.36 & 2.96 & 7.47 & 2.64 & 26.24 & 9.28356625 & 282.65 & 100 \\
\hline SILS, Kano & 308.06 & 80.40 & 14.13 & 3.69 & 3.53 & 0.92 & 1.71 & 0.45 & 6.36 & 1.66 & 2.53 & 0.66 & 46.84 & 12.2246581 & 383.16 & 100 \\
\hline $\begin{array}{l}\text { CAILS, } \\
\text { Missau }\end{array}$ & 194.21 & 83.50 & 10.54 & 4.53 & 5.81 & 2.50 & 3.45 & 1.48 & 5.41 & 2.33 & 6.41 & 2.76 & 6.76 & 2.90640182 & 232.59 & 100 \\
\hline $\begin{array}{l}\text { CILS, } \\
\text { Minna }\end{array}$ & 261.48 & 69.20 & 6.97 & 1.84 & 4.85 & 1.28 & 2.85 & 0.75 & 3.68 & 0.97 & 1.03 & 0.27 & 97 & 25.6708834 & 377.86 & 100 \\
\hline $\begin{array}{l}\text { CILS, } \\
\text { Ringim }\end{array}$ & 148.23 & 84.09 & 3.65 & 2.07 & 1.53 & 0.87 & 1.35 & 0.77 & 2.78 & 1.58 & 0.92 & 0.52 & 17.81 & 10.103818 & 176.27 & 100 \\
\hline CILS, Yola & 164.47 & 87.72 & 1.41 & 0.75 & 1.88 & 1.00 & 1.76 & 0.94 & 1.15 & 0.61 & 0.32 & 0.17 & 16.5 & 8.80046936 & 187.49 & 100 \\
\hline $\begin{array}{l}\text { CAILS, } \\
\text { Yauri }\end{array}$ & 192.79 & 81.05 & 14.84 & 6.24 & 4.63 & 1.95 & 2.95 & 1.24 & 7.29 & 3.06 & 0.88 & 0.37 & 14.5 & 6.09551034 & 237.88 & 100 \\
\hline $\begin{array}{l}\text { CILS, } \\
\text { Maiduguri }\end{array}$ & 406.56 & 88.61 & 18.03 & 3.93 & 6.43 & 1.40 & 2.44 & 0.53 & 7.26 & 1.58 & 1.2 & 0.26 & 16.9 & 3.68336167 & 458.82 & 100 \\
\hline
\end{tabular}

Source: Bursary Department of each institution 
Table 4 shows the utilization pattern of fund allocated to Colleges of Legal and Islamic Studies in Nigeria in the period between 2010 and 2014. The total financial allocation for all the selected colleges in Nigeria between 2010 and 2014 was N2.3 billion. Salaries and allowances consumed N1.9 billion representing $81.42 \%$. This remaining 18.58 was not adequate for maintenance or construction of new capital project in the colleges. No wonder in most of the colleges both academic and non-academic staff personally paid for their higher degree programmes with little or no assistance from the colleges.

This shows that each colleges of Legal and Islamic Studies in Nigeria spent an average of over $80 \%$ of her total financial allocation on staff salaries and allowances between 2010 and 2014. This position revealed that all the institutions were under funded by $20 \%$ when all sources are considered. This was confirmed by the study of Ipaye (2002) which revealed that teachers' tertiary institutions were funded by less than $20 \%$ of what could have met their needs. Polytechnic and universities were funded less than $35 \%$ and $65 \%$ respectively. Similarly, Afolabi (2004) also revealed that tertiary institutions in Kwara State were funded by $63 \%$. Therefore, there was a great variation between the amount needed to run the colleges effectively and what was disbursed to them between 2010 and 2014 .

\subsection{Internally Generated Revenue}

Table 5 shows the revenue the colleges generated between 2010 and 2014. 
Table 5: Internally Generated Revenue (2010 to 2014)

\begin{tabular}{|c|c|c|c|c|c|c|c|c|c|c|c|c|c|c|c|c|}
\hline \multirow[t]{2}{*}{ Institution } & \multicolumn{2}{|c|}{ Students fees } & \multicolumn{2}{|l|}{ Sports } & \multicolumn{2}{|c|}{$\begin{array}{l}\text { Examination } \\
\text { fees }\end{array}$} & \multicolumn{2}{|l|}{$\begin{array}{l}\text { Admission } \\
\text { forms }\end{array}$} & \multicolumn{2}{|c|}{$\begin{array}{l}\text { Agricultural } \\
\text { products }\end{array}$} & \multicolumn{2}{|c|}{$\begin{array}{c}\text { Rent from } \\
\text { college } \\
\text { property }\end{array}$} & \multicolumn{2}{|l|}{ Others } & \multicolumn{2}{|l|}{ Total } \\
\hline & Amount & $\%$ & Amount & $\%$ & Amount & $\%$ & Amount & $\%$ & Amount & $\%$ & Amount & $\%$ & Amount & $\%$ & Amount & $\%$ \\
\hline $\begin{array}{l}\text { CAILS, } \\
\text { Ilorin }\end{array}$ & $9,437,700$ & 71 & $1,473,685$ & 11 & $1,019,183$ & 8 & $1,398,623$ & 10 & - & & 10,000 & 0.07 & - & & $13,375,191$ & 100 \\
\hline SILS, Kano & $12,697,432$ & 41 & $6,391,241$ & 21 & $2,961,231$ & 10 & $4,939,523$ & 16 & - & & - & & $3,783,297$ & 12 & $31,042,718$ & 100 \\
\hline $\begin{array}{l}\text { CAILS, } \\
\text { Missau }\end{array}$ & $7,780,230$ & 47 & $2,861,931$ & 17 & $1,861,931$ & 11 & $2,539,200$ & 15 & $1,500,000$ & 9 & - & & - & & $16,493,061$ & 100 \\
\hline $\begin{array}{l}\text { CILS, } \\
\text { Minna }\end{array}$ & $6,196,924$ & 64 & $1,610,222$ & 17 & $1,012,500$ & 10 & 882,000 & 9 & - & & - & & - & & $9,701,646$ & 100 \\
\hline $\begin{array}{l}\text { CILS, } \\
\text { Ringim }\end{array}$ & $10,816,000$ & 41 & $3,864,000$ & 15 & $2,220,000$ & 8 & $1,984,000$ & 8 & $2,700,000$ & 10.2 & - & & $4,750,000$ & 18 & $26,334,000$ & 100 \\
\hline CILS, Yola & $5,000,000$ & 57 & $1,782,000$ & 20 & 986,000 & 11 & 987,400 & 11 & - & & - & & - & & $8,755,400$ & 100 \\
\hline $\begin{array}{l}\text { CAILS, } \\
\text { Yauri }\end{array}$ & $6,296,984$ & 53 & $2,482,000$ & 21 & $2,681,246$ & 22 & 480,000 & 4 & - & & - & & - & & $11,940,230$ & 100 \\
\hline $\begin{array}{l}\text { CILS, } \\
\text { Maiduguri }\end{array}$ & $14,980,000$ & 60 & $1,094,000$ & 4 & $2,500,000$ & 10 & $3,486,963$ & 14 & $2,864,861$ & 11.4 & - & & - & & $24,925,644$ & 100 \\
\hline Total & $73,205,270$ & 51 & $21,559,079$ & 15 & $15,242,091$ & 11 & $16,697,709$ & 12 & $7,064,861$ & 4.9 & 10,000 & 0.01 & $8,533,297$ & 5.9 & $142,312,307$ & 100 \\
\hline
\end{tabular}


Table 5 shows the revenue generated internally in Colleges of Legal and Islamic Studies in Nigeria between 2010 and 2014. On the whole, the total internally generated revenue in Colleges of Legal and Islamic studies in Nigeria between 2010 and 2014 stood at N142.6m. From this, students' tuition fees alone amounted to $\mathrm{N} 73.5 \mathrm{~m}$. This implies that students' tuition fees formed $51.56 \%$ of the revenue generated during the study period. The implication of this was that burden was placed on students in payment of tuition fees. This trend has resulted in over-enrolment of many students and commencement of degree programmes which are beyond the colleges' capacity especially with little or inadequate financial allocation to cater for the over-population. This result confirmed to the finding of Afolabi (2004) which revealed that the major source of fund in Kwara state owned tertiary institutions is tuition fees.

\section{Conclusion and Recommendations}

Based on the findings of this study, it appears that there is a general underfunding of the Colleges of Legal and Islamic Studies in Nigeria under the period considered. Even in the face of inflation in the country and the general increase in the number of staff and students in these colleges, there was little or no increase in the annual capital expenditures and monthly subventions. The colleges under this study would seem to be grossly under-financed when compared to other institutions in the country. On the basis of these findings, the following suggestions are made.

1. Improvement on the pattern of financial resources to these colleges is essential to enhance adequate funds and improve the existing status of financing the institutions.

2. There must be in-depth study of present allocation system to these institutions to cater for existing needs and demands

3. The management of these institutions should look at the possibility of working relationship with the proprietors of Islamiyyah schools to serve as feeder schools to colleges. This in turn may boost the IGR of these institutions.

4. There is the need to reduce per unit cost of student by increasing students' enrolment and ensuring that the quality of teaching is not lowered. This measure can also be achieved through the introduction of new programmes in the colleges.

5. Finally, further investigations should be carried out on the modalities for financing these colleges at state and national level so as to assist educational planners and authorities of these institutions in managing their resources effectively. 


\section{References}

Abdulkareem, A. Y. (1995). Introduction to research methods in education. Ibadan: Agboare publishers.

Afolabi, S. O. (2004). Influence of resource utilization on organizational effectiveness in Kwara state Government Owned Tertiary institutions. Unpublished doctoral thesis, Department of Educational Management, university of Ilorin, Ilorin

Ajayi, I. A. (1998. Towards effective financing of private secondary schools in Ekiti State. International Journal of Educational Management (IJEM), 2, (2) 26-30.

Federal Ministry of Information (1981). Fourth national development plan 1981-1985.

Federal Republic of Nigerian (2004). National policy on education. $4^{\text {th }}$ edition: Lagos: NERDC press

Ipaye, J. B. (2002). Education in Nigeria today: The lesson from the past and perspective for future. An inaugural lecture, university of Ilorin.

Lawal, S. (1989). An analysis of the sources of funding secondary schools in Ondo state. An unpublished thesis Ph.D. thesis, University of Ilorin.

Longe, R. S. (1984). Determinants of cost of secondary education: A study on educational cost in Nigeria. In Adesina and Ogunsaju (Eds.). Secondary education in Nigeria. University of Ife, press.

Nwankwo, J. I. (1981). Educational planning: theory and methods (Nigeria). Lahore: Izharsons.

Ojo, F. (1983). Nigeria University and high level manpower developments. Lagos: Lagos university press.

Onabamiro, (1982). Report on alternative source for financing education in Nigeria.

Omosidi, A. S. (2007). Relationship among funding, control system and organizational effectiveness in colleges of legal and Islamic studies in Nigeria. Unpublished doctoral thesis, Department of Educational Management, University of Ilorin, Ilorin. 